\title{
Pengaruh Kepemilikan Manajerial, Kepemilikan Institusional Dan Return On Equity Terhadap Nilai Prusahaan Pada Perusahaan Manufaktur Sektor Tekstil Dan Garemnt Yang Terdaftar Di Bei Periode 2010 - 2014
}

\author{
Indra Gunawan Siregar \\ Siregar@umt.ac.id \\ Januar Eky Pambudi \\ Jep@umt.ac.id
}

\section{Fakultas Ekonomi dan Bisnis Universitas Muhammadiyah Tangerang}

\begin{abstract}
ABSTRAK
Penelitian ini bertujuan untuk mengkaji dan menganalisis kepemilikan manajerial, kepemilikan institusional dan ROE terhadap nilai perusahaan. Desain penelitian ini menggunakan desain kausalitas eksplanatoris. Populasi yang digunakan dalam penelitian ini adalah perusahaan yang terdaftar di BEI khususnya sektor tekstil dan garment periode 2010-2014.

Hasil dari penelitian ini secara parsial menunjukkan bahwa variabel kepemilikan manajerial tidak berpengaruh terhadap nilai perusahaan. Sedangkan kepemilikan institusional berpengaruh negatif signifikan terhadap nilai perusahaan. Dan variabel ROE berpengaruh positif signifikan nilai perusahaan.

Temuan peneltian ini adalah tingkat penerapan GCG yang baik pada perusahaan tidak dilihat dari berapa besarnya kepemilikan saham salah satu pihak tertentu dalam perusahaan.
\end{abstract}

\section{Kata kunci : Kepemilikan Manajerial, Kepemilikan Institusional, ROE Dan Nilai Perusahaan.}

\section{PENDAHULUAN}

Perusahaan merupakan suatu organisasi yang terdiri dari atas kelompok orang yang bekerja untuk mencapai suatu tujuan. Kepentingan yang paling mendasar yaitu mendapatkan keuntungan serta kesejahteraan bagi para pemegang saham perusahaan. Peningkatan nilai perusahaan yang tinggi merupakan tujuan jangka panjang yang seharusnya dicapai perusahaan, yang akan tercermin dari harga pasar sahamnya, karena penilaian investor terhadap perusahaan dapat diamati melalui pergerakan saham perusahaan.

Nilai perusahaan sangat dibutuhkan, karena dengan peningkatan nilai perusahaan diharapkan mampu menarik pemegang saham untuk selalu berinvestasi pada perusahaan. Dengan peningkatan nilai perusahaan akan berpengaruh juga terhadap kesejahteraan karyawan, oleh sebab itu pihak yang ada di perusahaan dituntut untuk memanfaatkan kemampuan yang dimiliki semaksimal mungkin agar perusahaan lebih unggul dalam bersaing dibanding perusahaan lain.

Perbedaan kepentingan antara manajer dan pemegang saham ini mengakibatkan timbulnya konflik yang biasa disebut agency conflict. Hal tersebut 
terjadi karena manajer mengutamakan kepentingan pribadi, sebaliknya pemegang saham tidak menyukai kepentingan pribadi dari manajer karena apa yang dilakukan manajer tersebut akan menambah biaya bagi perusahaan sehingga menyebabkan penurunan keuntungan perusahaan dan berpengaruh terhadap harga saham sehingga menurunkan nilai perusahaan. Adanya agency problem tersebut akan menyebabkan tidak tercapainya tujuan keuangan perusahaan, yaitu meningkatkan nilai perusahaan dengan cara memaksimumkan kekayaan pemegang saham.

Hadirnya corporate governance dalam pemulihan krisis di Indonesia menjadi mutlak diperlukan, mengingat good corporate governance mensyaratkan suatu pengelolaan yang baik dalam sebuah organisasi (Hastuti, 2005). Corporate governance yang mengandung empat unsur penting yaitu keadilan, transparansi, pertanggungjawaban dan akuntabilitas, diharapkan dapat menjadi suatu jalan dalam mengurangi konflik keagenan. Dengan adanya tata kelola perusahaan yang baik, diharapkan nilai perusahaan akan dinilai dengan baik oleh investor. Ada empat mekanisme corporate governance yang sering dipakai dalam berbagai penelitian mengenai corporate governance yang bertujuan untuk mengurangi konflik keagenan, yaitu komite audit, komisaris independen, kempelikan institusional, kepemilikan manajemen (Rahmawati, 2007).

Kepemilikan manajerial dimaksudkan untuk memberikan kesempatan manajer terlibat dalam kepemilikan saham sehingga dengan keterlibatan kedudukan manajer sejajar dengan pemilik perusahaan (pemegang saham). Dengan adanya kepemilikan saham yang besar oleh manajemen dapat mensejajarkan kepentingan manajer dan pemegang saham sehingga dapat mengurangi konflik keagenan, karena manajer akan termotivasi untuk meningkatkan kinerja dan bertanggung jawab meningkatkan kemakmuran pemilik atau pemegang saham (prinsipal) sehingga nilai perusahaan juga akan meningkat. Yadyana dan Wati (2011) menjelaskan, kepemilikan saham oleh pihak manajemen pada dasarnya adalah satu upaya untuk mensejajarkan antara kepentingan manajemen tersebut dengan kepentingan para pemegang saham.

Kepemilikan institusional atau kepemilikan saham oleh investor yang berasal dari pihak luar perusahaan, seperti berasal dari sektor keuangan perusahaan efek, perusahan asuransi, perbankan, perusahaan investasi, dan dana pensiun (Aminudin, 2004). Dengan adanya kepemilikan saham yang besar oleh institusi maka akan mendorong peningkatan pengawasan (monitoring) yang lebih optimal dan efektif terhadap kinerja manajemen, sehingga dapat meminimalisasi konflik keagenan dan dapat meningkatkan nilai perusahaan (Haruman, 2007). Haruman (2008) menyatakan bahwa struktur kepemilikan perusahaan dapat mempengaruhi pencapaian tujuan perusahaan. Struktur kepemilikan akan mempengaruhi keputusan keuangan yang terdiri dari keputusan investasi, pendanaan dan kebijakan deviden yang pada akhirnya akan mempengaruhi nilai perusahaan.

Struktur kepemilikan oleh beberapa peneliti dipercaya mampu memepengaruhi jalannya perusahaan yang pada akhirnya berpengaruh pada kinerja perusahaan dalam mencapai tujuan perusahaan yaitu memaksimalisasi nilai perusahaan. Hal ini disebabkan karena adanya kontrol yang mereka miliki 
(Wahyudi dan Prawesti, 2006). Struktur kepemilikan publik dan masalah keagenan merupakan isu sentral dalam literatur keuangan. Semakin besar dan luas usaha suatu perusahaan, pemilik tidak bisa mengelola sendiri perusahaannya secara langsung sehingga memicu timbulnya masalah keagenan. Masalah keagenan pertama terjadi apabila kepemilikan saham tersebar, sehingga pemegang saham secara individual tidak dapat mengendalikan manajemen. Akibatnya pemegang saham mayoritas memiliki kendali mutlak dibanding pemegang saham minoritas, sehingga pemegang saham mayoritas bisa melakukan tindakan yang menguntungkan dirinya, tetapi kemungkinan merugikan pemegang saham minoritas (La Porta et al. 1999).

Dewan komisaris memiliki tanggungjawab dan mempunyai wewenang, mensupervisi kebijakan dan tindakan Direksi, dan memberikan nasihat kepada Direksi bila diperlukan. Untuk melakukan hal tersebut, dewan komisaris dapat berdasarkan prosedur-prosedur yang telah ditetapkan, atau meminta nasihat profesional yang independen dan/atau menetapkan panitia khusus (Tunggal, 2011: 37). Dewan komisaris memegang peranan yang sangat penting dalam perusahaan, terutama dalam pelaksanaan good corporate governance. Fungsi kontrol yang dilakukan oleh dewan komisaris mewakili mekanisme internal utama untuk mengontrol prilaku oportunistik manajemen sehingga dapat membantu menyelaraskan kepentingan pemegang saham dan manajer (Jensen, 1993).

Tolak ukur lain yang digunakan untuk mengukur kinerja perusahaan adalah rasio profitabilitas. Rasio profitabilitas adalah rasio yang digunakan untuk mengukur efektifitas manajemen berdasarkan hasil pengembalian dari penjualan investasi serta kemampuan perusahaan menghasilkan laba (profit) yang akan menjadi dasar pembagian deviden perusahaan. Rasio yang paling umum digunakan untuk mengukur profitabilitas adalah ROA dan ROE.

\section{TELAAH PUSTAKA DAN TEORI}

\section{Agency Theory}

Teori ini muncul setelah terpisahnya kepemilikan perusahaan dengan pengelolaan. Dalam agency theory, principal adalah pihak-pihak yang menyerahkan sebagian atau seluruh kekayaannya (wealth) untuk dikembangkan oleh pihak lain (Tunggal, 2011:25). Menurut Darmawati, dkk (2004) mengatakan teori keagenan ditekankan untuk mengatasi dua permasalahan yang dapat terjadi dalam hubungan keagenan.

\section{Signaling Theory}

Teori sinyal membahas mengenai dorongan perusahaan untuk memberikan informasi kepada pihak eksternal. Dorongan tersebut disebabkan karena terjadinya asimetri informasi antara pihak manajemen dan pihak eksternal. Untuk mengurangi asimetri informasi maka perusahaan harus mengungkapkan informasi yang dimiliki, baik informasi keuangan maupun non keuangan. Teori signal menurut Spence (1973) dapat disimpulkan merupakan sebuah asimetri informasi yang saling berkaitan antara pihak pengirim dan penerima, dimana pengirim memiliki informasi penuh sedangkan pihak penerima tidak memiliki informasi, kemudian pengirim informasi memberikan sinyal kepada penerima.

\section{Value Relevance Theory}


Relevansi nilai informasi akuntansi mempunyai arti kemampuan informasi akuntansi untuk menjelaskan nilai perusahaan ( Beaver, 1968). Penelitian mengenai value relevance menjadi penting karena terdapat klaim yang menyatakan bahwa laporan keuangan berbasis cost historis telah kehilangan sebagian besar relevansinya bagi investor yang diakibatkan oleh perubahan besarbesaran dalam perekonomian, yaitu dari perekonomian industrial ke perekonomian berteknolgi tinggi dan berorientasi jasa ( Francis dan schipper, 1998).

\section{Nilai Perusahaan}

Nilai perusahaan adalah sangat penting karena dengan nilai perusahaan yang tinggi akan diikuti oleh tingginya kemakmuran pemegang saham (Brigham dan Gapenski, 1996). Semakin tinggi harga saham semakin tinggi nilai perusahaan. Nilai perusahaan yang tinggi menjadi keinginan para pemilik perusahaan, sebab dengan nilai yang tinggi menunjukkan kemakmuran pemegang saham juga tinggi. Menurut Fama (1978) nilai perusahaan akan tercermin dari harga sahamnya. Harga pasar dari saham perusahaan yang terbentuk antara pembeli dan penjual disaat terjadi transaksi disebut nilai pasar perusahaan, karena harga pasar saham dianggap cerminan dari nilai asset perusahaan sesungguhnya.

\section{Good Corporte Governance}

Good corporate governance adalah suatu hal yang berkaitan dengan pengambilan keputusan yang efektif yang bersumber dari budaya perusahaan, etika, nilai, sistem, proses bisnis, kebijakan dan struktur organisasi perusahaan yang bertujuan untuk mendorong, mendukung pengembangan perusahaan, pengelolaan sumber daya dan resiko secara efisien, efektif dan pertanggungjawaban perusahaan kepada pemegang saham dan stakeholder lainnya.

\section{Kepemilikan manajerial}

Kepemilikan manajerial adalah tingkat kepemilikan saham pihak manajemen yang secara langsung ikut aktif dalam pengambilan keputusan. Kepemilikan manajerial diukur dengan menghitung persentase (\%) jumlah lembar saham yang dimiliki oleh pihak manajemen yaitu manajer, komisaris terafiliasi (diluar komisaris independen) dan direksi dibagi dengan total jumlah saham yang beredar. Dalam kepemilikan saham oleh manajerial, diharapkan manajer akan bertindak sesuai dengan keinginan para principal karena manajer akan termotivasi untuk meningkatkan kinerja.

\section{Kepemilikan institusional}

Kepemilikan institusional memiliki kemampuan untuk mengendalikan pihak manajemen melalui monitoring secara efektif sehingga mengurangi tindakan manajemen melakukan manajemen laba. Persentase saham tertentu yang dimiliki oleh institusi dapat mempengaruhi proses penyusunan laporan keuangan yang tidak menutup kemungkinan terdapat akrualisasi sesuai kepentingan pihak manajemen (Boediono, 2005)

\section{Profitabilitas}

Kinerja keuangan perusahaan merupakan salah satu faktor yang dilihat oleh calon investor untuk menentukan investaasi saham. Bagi perusahaan, menjaga dan 
meningkatkan kinerja keuangan suatu keharusan agar saham tersebut tetap eksis dan tetap diminati investor. Laporan keuangan yang diterbitkan perusahaan merupakan cerminan dari kinerja keuangan perusahaan. Menurut Analisa (2011) nilai perusahaan dapat pula dipengaruhi oleh besar kecilnya profitabilitas yang dihasilkan oleh perusahaan. Profitabilitas adalah kemampuan suatu perusahaan untuk menghasilkan laba selama periode tertentu. Pemilihan ROE sebagai moderasi dari pengukuran profitabilitas adalah didasarkan pada positive accounting theory yaitu the bonus plan hypotesis. Perusahaan memiliki rencana pemberian bonus, manajer perusahaan akan lebih memilih metode akuntansi yang dapat menggeser laba dari masa depan ke masa kini sehingga dapat menaikkan laba.

\section{Hubungan Antar Variabel \\ Kepemilikan manajerial dengan nilai perusahaan}

Dengan adanya salah satu mekanisme GCG diharapkan monitoring terhadap manajer perusahaan lebih efektif sehingga dapat meningkatkan kinerja perusahaan dan nilai perusahaan. Perusahaan yang menerapkan sistem GCG diharapkan kinerja perusahaan akan meningkat menjadi lebih baik, dengan meningkatnya kinerja perusahaan diharapkan juga dapat meningkatkan harga saham perusahaan sebagai indikator dari nilai perusahaan sehingga nilai perusahaan akan tercapai. Susanti, dkk (2010) menemukan bahwa kepemilikan manajerial berpengaruh terhadap nilai perusahaan.

\section{Kepemilikan institusional dengan nilai perusahaan}

Dalam menjalankan aktivitas perusahaan, ada beberapa pihak yang berperan dalam menentukan kebijakan, seperti manajerial dan institusional. Dalam penelitian ini, pihak institusional adalah pemegang saham, yang pada umumnya adalah institusional. Kepemilikan saham instituisional dapat membantu untuk melakukan monitoring perusahaan. Dengan demikian, kemungkinan manajer untuk mencapai kepentingan pribadi akan berkurang. Permanasari (2013) menyatakan bahwa tingginya kepemilikan institusi akan meningkatkan pengawasan terhadap perusahaan. Pengawasan yang tinggi ini kemungkinan akan meminimalisasi tingkat penyelewengan-penyelewengan yang dilakukan oleh pihak manajer.

\section{Return on Equity dengan nilai perusahaan}

Salah satu alasan utama perusahaan beroperasi adalah menghasilkan laba yang bermanfaat bagi para pemegang saham. Ukuran dari keberhasilan pencapaian alasan ini adalah semakin besar ROE dan ROA mencerminkan kemampuan perusahaan dalam menghasilkan keuntungan yang tinggi bagi pemegang saham. Hal ini berdampak terhadap peningkatan nilai perusahaan.

\section{Hipotesis Penelitian}

\section{Pengaruh Kepemilikan Manajerial terhadap Nilai Perusahaan}

Keefektifan kepemilikan manajerial dalam mengatasi konflik keagenan berkaitan dengan kepentingan manajemen untuk mengelola perusahaan secara 
efisien dalam rangka meningkatkan nilai perusahaan. Rupilu (2011) menemukan bahwa kepemilikan manajerial berpengaruh terhadap nilai perusahaan.

H1 : Terdapat pengaru positif kepemilikan manajerial terhadap nilai perusahaan

\section{Pengaruh Kepemilikan Institusional terhadap Nilai Perusahaan}

Kepemilikan institusional dapat mengurangi masalah keagenan sebab timbulnya konsentrasi kepemilikan yang tinggi akan mendorong pemegang saham pada posisi yang kuat untuk mengendalikan manajemen secara efektif. Dengan adanya hal tersebut, maka diharapkan manajemen akan terdorong untuk bertindak sesuai dengan kepentingan pemegang saham. Sukirni (2012) menyimpulkan bahwa kepemilikan institusional berpengaruh terhadap nilai perusahaan.

H2 :Terdapat pengaruh positif kepemilikan institusional terhadap nilai perusahaan.

\section{Pengaruh Return On Equity terhadap Nilai Perusahaan}

Salah satu tujuan utama adalah menghasilkan laba yang bermanfaat bagi pemeganga saham. Ukuran keberhasilan perusahaan dapat dilihat dari angka ROE yang berhasil dicapai. Semakin besar ROE mencerminkan kemampuan perusahaan memperoleh keuntungan untuk pemegang saham. Wardoyo dan Veronica (2013) menunjukkan bahwa ROE memiliki pengaruh secara signifikan terhadap nilai perusahaan.

$\mathrm{H} 4$ :Terdapat pengaruh positif return on equity terhadap nilai perusahaan

\section{METODE PENELITIAN}

\section{Populasi Dan Sampel Penelitian}

Populasi dalam penelitian ini adalah perusahaan manufaktur sektor tekstil dan garment yang terdaftar di BEI periode tahun 2010-2014 adalah sebanyak 17 perusahaan. Pengambilan sampel dalam penelitian ini dilakukan dengan menggunakan teknik non random sampling. Salah satu teknik pengambilan sampling yang digunakan adalah metode purposive sampling. Pemilihan sampel dengan metode purposive sampling dilakukan agar peneliti mendapatkan sampel yang representative sesuai kriteria yang ditentukan (Nurlela dan Islahuddin, 2008).

\section{Definisi Dan Pengukuran Variabel Nilai Perusahaan}

Nilai perusahaan diproksikan dengan menggunakan Tobin's Q diberi symbol Q yaitu merupakan nilai perusahaan yang diukur dengan kapitalisasi pasar dan ekuitas ditambah nilai buku hutang dibagi dengan nilai buku total aktiva.

\section{Kepemilikan Manajerial}

Kepemilikan manajerial adalah kepemilikan saham perusahaan oleh manajer atau dengan kata lain manajer tersebut sekaligus sebagai pemegang saham (Nugroho, 2012).

\section{Kepemilikan Institusional}


Kepemilikan institusional adalah jumlah persentase hak suara yang dimiliki oleh institusi (Bainer et al., 2003)

\section{Return On Equty}

ROE adalah proporsi laba bersih setelah pajak dibagi dengan modal sendiri.

\section{Pengukuran Variabel}

\begin{tabular}{|c|c|c|c|}
\hline No. & Variabel & Pengukuran & Skala \\
\hline 1 & $\begin{array}{l}\text { Kepernilikan } \\
\text { Manajerial }\end{array}$ & $\mathrm{KM}=\frac{\sum \text { Saham Manajerial }}{\sum \text { Saham Beredar }} \times 100 \%$ & Rasio \\
\hline 2 & $\begin{array}{l}\text { Kepernilikan } \\
\text { Institusional }\end{array}$ & $\mathrm{KI}=\frac{\sum \text { Saham Institusi }}{\sum \text { Saham Beredar }} \quad \mathrm{x}_{100 \%}$ & Rasio \\
\hline 3 & $\begin{array}{l}\text { Ukuran Dewan } \\
\text { Komisaris }\end{array}$ & $\mathrm{UDK}=\sum$ Dewan Komisaris & Nominal \\
\hline 4 & $\begin{array}{l}\text { Return On } \\
\text { Equity }\end{array}$ & ROE $=\frac{\text { Laba bersih }}{\text { Modal Sendiri }}$ & Rasio \\
\hline 5 & $\begin{array}{l}\text { Konservatisme } \\
\text { Akuntansi }\end{array}$ & $A C_{\text {it }}=N I_{\text {it }}-C F_{\text {it }}$ & Rasio \\
\hline 6 & $\begin{array}{l}\text { Nilai } \\
\text { Perusahaan } \\
(\text { Tobin's } Q)\end{array}$ & $Q=\frac{\left.\left.\left(\left(C P^{*} \cdot \mathrm{JS}\right)+\mathrm{TL}\right)-\mathrm{CA}\right)\right)}{\mathrm{TA}}$ & Rasio \\
\hline
\end{tabular}

Analisis Regresi

Metode analisis yang digunakan adalah metode analsis kuantitatif yaitu untuk menganalisis informasi kuantitatif (dapat diukur, diuji dan ditransformasikan dalam bentuk persamaan, tabel dan sebagainya). Model analsis yang digunakan adalah model regresi linear berganda dengan metode least square yang bertujuan untuk mengetahui pengaruh variabel independen terhadap variabel dependen secara langsung.

\section{Teknik Penaksiran Model}

Sriyana (2014:81) hal terpenting dalam melakukan analisis regresi data panel adalah pemilihan metode estimasi yang digunakan. Sejauh ini terdapat tiga model pendekatan estimasi yang biasa digunakan pada regresi data panel, yaitu pendekatan dengan model common effects, fixed effects, dan random effects.

\section{Common Effect Model}

Menurut Sriyana (2014:108) sistematika model common effects adalah menggabungkan antara data time series dan data cross-section ke dalam data panel (pool data).

\section{Fixed Effect Model}

Menurut Sriyana (2014:121) kondisi data-data ekonomi pada tiap obyek yang dianalisis sangat mungkin saling berbeda, bahkan satu obyek pada suatu waktu akan sangat berbeda dengan kondisi obyek tersebut pada waktu yang lain.

\section{Random Effect Model}

Sriyana (2016:153) dapat dikatakan bahwa model random effects ini merupakan alternatif solusi jika fixed effects tidak tepat. Dibawah ini adalah uji yang dilakukan dalam memilih model yaitu : 


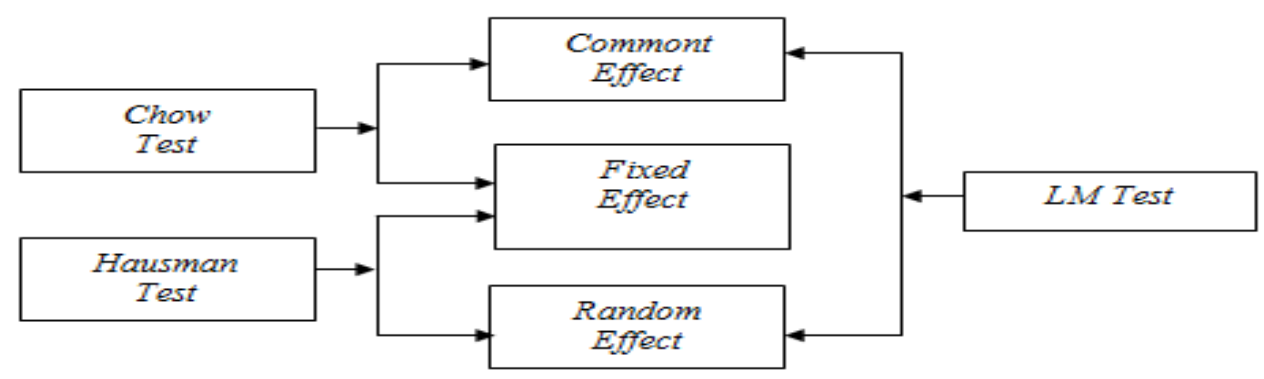

\section{PEMBAHASAN HASIL PENELITIAN}

\section{Pengujian hipotesis}

Berdasarkan hasil uji analisis regresi data panel yang dilakukan maka model regresi yang dipilih adalah random effect model. Hasil ini bisa dilihat dari hasil uji langrange multiplier yang menunjukkan bahwa nilai probability dari BreuschPagan sebesar $0,0305<0,05$. Dari hasil tersebut maka persamaan regresi yang diperoleh adalah sebagai berikut :

$\mathrm{NP}=-\mathbf{0 , 0 3 5}+4,143 \mathrm{KM}-3,450 \mathrm{KI}+0,372 \mathrm{ROE}+\varepsilon$

Ha1 : Tidak terdapat pengaruh kepemilikan manajerial terhadap nilai perusahaan

Ha2 : Terdapat pengaruh signifikan negatif kepemilikan institusional terhadap nilai perusahaan

Ha3 : Terdapat pengaruh siginfikan positif return on equity terhadap nilai perusahaan

\section{Pembahasan Hasil Penelitian}

\section{Pengaruh Kepemilikan Manajerial Terhadap Nilai Perusahaan}

Keberadaan kepemilikan manajerial diharapkan efektif dalam mengatasi konflik keagenan berkaitan dengan kepentingan manajemen untuk mengelola perusahaan secara efisien dalam rangka meningkatkan nilai perusahaan pada sektor tekstil dan garment. Manajer sebagai mekanisme pengendali dalam penyusunan laporan laba kurang memberikan pengaruh kepada pasar melalui informasi laba dalam laporan keuangan sehingga nilai perusahaan tidak mengalami kenaikan. Kepemilikan saham yang sangat kecil membuat manajerial tidak bekerja sesuai dengan tujuan perusahaan, sehingga cenderung mementingkan diri sendiri.

Hasil ini tidak lepas dari kondisi perusahaan tekstil dan garment yang sedang mengalami kesulitan. Adanya penghapusan regulasi terkait dengan kemudahan impor tujuan ekspor yang membuat perusahaan mengeluarkan biaya pajak yang lebih besar dan ditambah lagi dengan harga bahan baku yang naik. Sehingga berpengaruh terhadap keuntungan perusahaan yang menurun dan bermuara pada menurunnya nilai perusahaan.

\section{Pengaruh Kepemilikan Institusional Terhadan Nilai Perusahaan}

Keberadaan pemegang saham institusi yang diharapkan memiliki kemampuan monitoring yang lebih baik tidak mampu membuat tata kelola perusahaan menjadi transparan. Ada indikasi pemegang saham institusi hanya mementingkan diri sendiri atau kepentingan institusinya tanpa melihat kepentingan pemegang saham yang lain. Keadaan ini akan memberi pengaruh 
yang besar pada perusahaan, karena sebelumnya telah ada kasus manifulasi laporan keuangan pada perusahaan sejenis yaitu PT. Great River International.

Implikasinya, perusahaan tidak mampu memberikan informasi laporan keuangan yang fairness sehingga investor tidak akan bereaksi di pasar karena informasi laporan keuangan terdapat kandungan informasi bad news. Kondisi tersebut membuat pemegang saham lain beranggapan adanya ekspropriasi dari pemegang saham institusi dan menarik sahamnya dari perusahaan sehingga harga saham akan turun yang diikuti dengan menurunnya nilai perusahaan. Hasil ini berbeda dengan penelitian yang dilakukan oleh Sukirni (2012) yang menemukan bahwa kepemilikan institusional berpengaruh positif terhadap nilai perusahaan.

\section{Pengaruh ROE terhadap Nilai Perusahaan}

Laba yang dihasilkan oleh perusahaan mampu meningkatkan harga saham perusahan yang berimbas pada meningkatnya nilai perusahaan. Kemampuan perusahaan untuk menghasilkan profit dipandang positif oleh para investor. Sehingga investor mengambil keputusan untuk membeli saham perusahaan. Artinya, saham yang diperdagangkan perusahaan masih laku dijual kepada investor. Para pelaku pasar modal menggunakan informasi laba tersebut untuk melakukan transaksi jual beli saham perusahaan. Hasil ini juga menegaskan kepada investor bahwa perusahaan mampu mengelola modal yang sudah ditanamkan oleh investor. Dengan hasil ini investor juga akan memperoleh return atas investasinya pada perusahaan. Sejalan dengan penelitian Mahendra dkk (2012) juga menemukan bahwa profitabilitas berpengaruh positif terhadap nilai perusahaan.

\section{Temuan Penelitian}

Temuan penelitian yaitu tingkat penerapan GCG yang baik pada perusahaan tidak dilihat dari berapa besarnya kepemilikan saham oleh pihak tertentu. Pada perusahaan yang menjadi sampel menunjukkan bahwa sahamnya dikuasai lebih banyak oleh lembaga atau institusi, akan tetapi tidak menjamin perusahaan berjalan dengan baik dalam kegiatan operasi.

\section{KESIMPULAN DAN SARAN}

Berdasarkan hasil dan pembahasan, kesimpulan yang diperoleh adalah pertama, secara parsial hanya variabel kepemilikan institusional yang berpengaruh negatif signifikan sedangkan ROE berpengaruh positif terhadap nilai perusahaan. Sedangkan variabel kepemilikan manajerial tidak berpengaruh terhadap nilai perusahaan.

Saran untuk penelitian selanjutnya, sebaiknya menambah variabel independen lain yang dianggap berpengaruh terhadap nilai perusahaan. Dan diharapkan bagi perusahaan yang diteliti untuk mampu menerapkan GCG yang baik untuk meningkatkan nilai perusahaan.

\section{Daftar pustaka}

Dewi, Sri, Ayu dan Wirajaya, Ary, 2013. ISSN. Pengaruh Struktur Modal, Profitabilitas da Ukuran Perusahaan pada Nilai Perusahaan. Bali. 
Mardiasari, Nilla, 2012. Universitas Islam Sunan Kalijaga. Pengaruh ROA Terhadap Nilai Perusahaan Dengan Pengungkapan GCG Sebagai Variabel Pemoderasi (Studi Pada Perusahaan yang Masuk Daftar Efek Syariah Periode 2007-2010). Yogyakarta.

Noorlaila, 2011. Universitas Diponegoro. Analisis Pengaruh GCG Terhadap Nilai Perusahaan. Semarang.

Indriani, Eni, 2012. Distribusi Edisi ke XXXII. Mekanisme Corporate Governance sebagai pemoderasi antara Kualitas Laba dan Nilai Perusahaan. Universitas Mataram.

Putri, Rizka, Kharisma, 2011. Universitas Diponegoro. Analisis pengaruh Corporate Governance, Struktur Kepemilikan, dan Cash Holdings Terhadap Nilai Perusahaan. Semarang.

Ratih, Suklimah, 2011. Jurnal Kewirausahan. Pengaruh GCG Terhadap Nilai Perusahaan Dengan Kinerja Keuangan Sebagai Variabel Intervening pada Perusahaan Peraih The Indonesian Most Trusted Company-CGPI. ISSN, 1978-4724.

Rupilu, Wilsna, 2011. Jurnal Akuntansi, Manajemen Bisnis dan Sektor Publik. Pengaruh Mekanisme CG Terhadap Kualitas Laba dan Nilai Perusahaan pada Perusahaan Manufaktur yang Terdaftar di BEI. Surabaya.

Retno, Reny, Dyah dan Priantinah, 2012. Universitas Negeri Yogyakarta. Pengaruh GCG dan Pengungkapan CSR Terhadap Nilai Perusahaan.

Siahaan, Anton, Luvi, 2011. Jurnal Murni Sadar. Pengaruh Kinerja Keuangan Terhadap Nilai Perusahaan Dengan Pengungkapan CSR Dan GCG Sebagai Variabel Pemoderasi.

Wardoyo dan Veronica, Theodora, Martina, 2013. Jurnal Dinamika Manajemen. Pengaruh GCG, CSR dan Kinerja Keuangan Terhadap Nilai Perusahaan. Universitas Gunadarma. Jakarta.

Suaidah, Sitta, 2010. Universitas Perbanas. Pengaruh ROA dan ROE Terhadap Nilai Perusahaan Dengan Pengungkapan CSR dan Kepemilikan Manajerial sebagai Pemoderasi. Surabaya.

Susanti, dkk. 2010. Simposium Nasional Keuangan. Analisis Pengaruh Mekanisme CG Terhadap Nilai Perusahaan Dengan Kualitas Laba sebagai Variabel Intervening pada Perusahaan Manufaktur yang Terdaftar di BEI Periode 2004-2007. Surakarta.

Sari, Enggar dan Riduwan, Akhmad, 2013. Jurnal Ilmu dan Riset Akuntansi. Pengaruh Corporate Governance Terhadap Nilai Perusahaan : Kualitas Laba sebagai Variabel Intervening. Surabaya.

Sutrisno, 2010. Universitas Diponegoro. Pengaruh Earnings Management Terhadap Nilai Perusahaan Dengan Mekanisme CG Sebagai Moderating Variable. Semarang.

Sambora, dkk, 2014. Jurnal Administrasi Bisnis. Pengaruh Leverage dan Profitabilitas terhadap Nilai Perusahaan. Malang.

Suyanti, dkk, 2010. Universitas Sebelas Maret. Pengaruh Mekanisme Corporate Governance Terhadap Nilai Perusahaan Dengan Kualitas Laba Sebagai Variabel Intervening. Surakarta. 
Tjhen, Fabian, Tjandra, dkk, 2012. ISSN. Pengaruh Konservatisme Akuntansi Terhadap Nilai Perusahaan Dimoderasi Oleh GCG.

Tjondro, David dan Wilopo, R, 2011. Journal of Business and Banking. Pengaruh Good Corporate Governance Terhadap Profitabilitas dan Kinerja Saham Perusahaan Perbankan Yang Tercatat di BEI. Surabaya.

Yuyetta, Etna Nur, 2009. Jurnal Akuntansi dan Auditing. Pengaruh Leverage Terhadap Nilai Perusahaan pada Masa Krisis : Pengujian Empiris di Indonesia. Semarang.

Tunggal, Amin, Djaja, 2011. Teori dan Kasus Internal Auditing. HARVARINDO.

\section{LAMPIRAN-LAMPIRAN}

\section{COMMON EFFECT}

Dependent Variable: NP

Method: Panel Least Squares

Date: 05/31/17 Time: 10:44

Sample: 20102014

Periods included: 5

Cross-sections included: 15

Total panel (balanced) observations: 75

\begin{tabular}{lrlrl}
\hline \hline \multicolumn{1}{c}{ Variable } & Coefficient & \multicolumn{1}{c}{ Std. Error } & t-Statistic & Prob. \\
\hline \multicolumn{1}{c}{ C } & -0.034964 & 0.591920 & -0.059069 & 0.9531 \\
\multicolumn{1}{c}{ KM } & 4.142812 & 5.921708 & 0.699597 & 0.4865 \\
KI & -3.450052 & 1.107224 & -3.115949 & 0.0026 \\
\multicolumn{1}{c}{ ROE } & 0.371482 & 0.150487 & 2.468536 & 0.0160 \\
\hline \hline R-squared & 0.165734 & Mean dependent var & 0.342133 \\
Adjusted R-squared & 0.130483 & S.D. dependent var & 2.498608 \\
S.E. of regression & 2.329900 & Akaike info criterion & 4.581386 \\
Sum squared resid & 385.4187 & Schwarz criterion & 4.704985 \\
Log likelihood & -167.8020 & Hannan-Quinn criter. & 4.630738 \\
F-statistic & 4.701579 & Durbin-Watson stat & 2.053611 \\
Prob(F-statistic) & 0.004737 & & \\
\hline \hline
\end{tabular}

\section{FIXED EFFECT}

Dependent Variable: NP

Method: Panel Least Squares

Date: 05/31/17 Time: 10:45

Sample: 20102014

Periods included: 5

Cross-sections included: 15

Total panel (balanced) observations: 75

\begin{tabular}{lllll}
\hline \hline Variable & Coefficient & Std. Error & t-Statistic & Prob. \\
\hline \hline
\end{tabular}




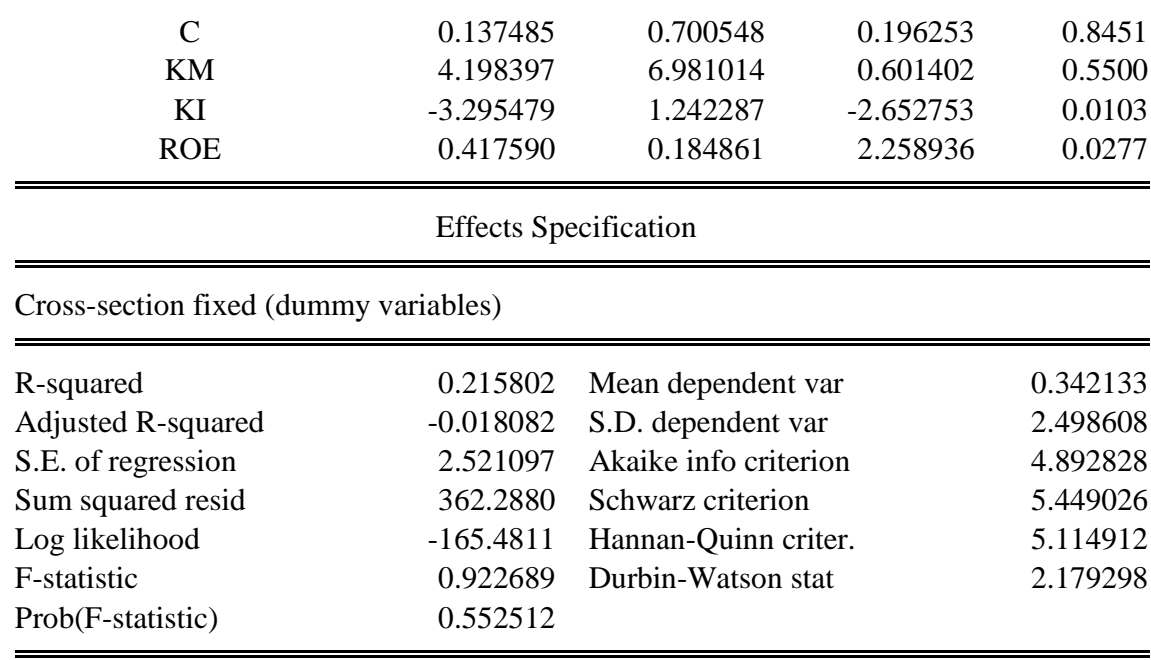

\section{RANDOM EFFECT}

Dependent Variable: NP

Method: Panel EGLS (Cross-section random effects)

Date: 05/31/17 Time: 10:47

Sample: 20102014

Periods included: 5

Cross-sections included: 15

Total panel (balanced) observations: 75

Swamy and Arora estimator of component variances

\begin{tabular}{|c|c|c|c|c|}
\hline Variable & Coefficient & Std. Error & t-Statistic & Prob. \\
\hline $\mathrm{C}$ & -0.034964 & 0.640494 & -0.054589 & 0.9566 \\
\hline $\mathrm{KM}$ & 4.142812 & 6.407658 & 0.646541 & 0.5200 \\
\hline $\mathrm{KI}$ & -3.450052 & 1.198085 & -2.879639 & 0.0053 \\
\hline ROE & 0.371482 & 0.162836 & 2.281325 & 0.0255 \\
\hline \multicolumn{5}{|c|}{ Effects Specification } \\
\hline & & & S.D. & Rho \\
\hline Cross-section random & & & 0.000000 & 0.0000 \\
\hline Idiosyncratic random & & & 2.521097 & 1.0000 \\
\hline \multicolumn{5}{|c|}{ Weighted Statistics } \\
\hline R-squared & 0.165734 & \multicolumn{2}{|l|}{ Mean dependent var } & 0.342133 \\
\hline Adjusted R-squared & 0.130483 & \multicolumn{2}{|l|}{ S.D. dependent var } & 2.498608 \\
\hline S.E. of regression & 2.329900 & \multicolumn{2}{|l|}{ Sum squared resid } & 385.4187 \\
\hline F-statistic & 4.701579 & \multicolumn{2}{|l|}{ Durbin-Watson stat } & 2.053611 \\
\hline Prob(F-statistic) & 0.004737 & & & \\
\hline
\end{tabular}

Unweighted Statistics 


\begin{tabular}{llll} 
R-squared & 0.165734 & Mean dependent var & 0.342133 \\
Sum squared resid & 385.4187 & Durbin-Watson stat & 2.053611 \\
\hline
\end{tabular}

\section{LANGRANGE MULTIPLIER}

Lagrange Multiplier Tests for Random Effects

Null hypotheses: No effects

Alternative hypotheses: Two-sided (Breusch-Pagan) and one-sided (all others) alternatives

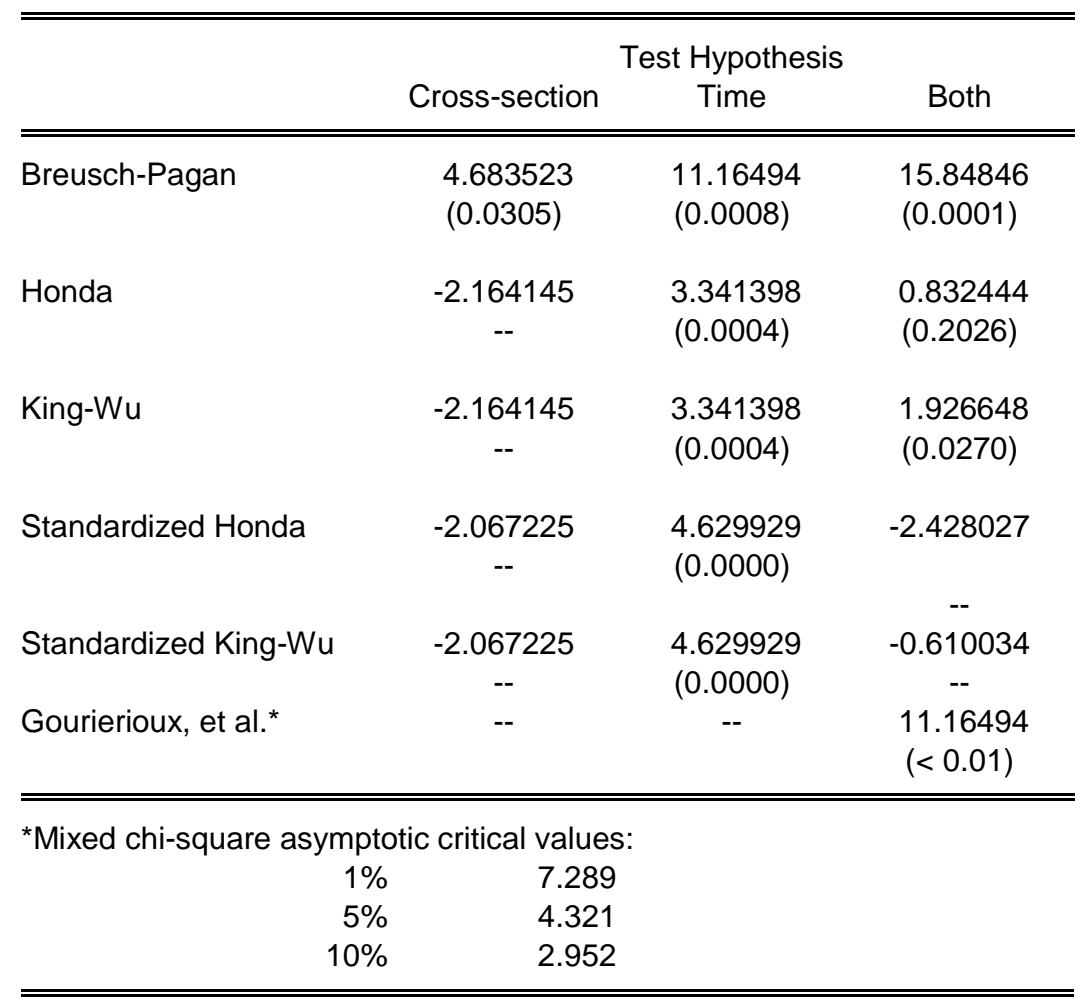

